\title{
Teatro abierto 1981. Selección de fuentes primarias del archivo Dragún
}

\author{
(1)ene Villagra \\ Licenciada en Historia (Facultad de Filosofía y Letras, Universidad de Buenos \\ Aires), Argentina \\ vivi-facul@hotmail.com
}

\begin{abstract}
A cuarenta años de Teatro Abierto, la Dirección de la Revista Teatro XXI propone homenajear el acontecimiento, mediante una selección de testimonios. La misma está compuesta por textos, material fotográfico, recortes de artículos de diarios y revistas, ubicados en el Archivo Personal de Osvaldo Dragún, archivo que la actriz María Ibarreta donó, en 2006, al Instituto de Historia del Arte Argentino y Latinoamericano "Luis Ordaz", de la Facultad de Filosofía y Letras, de la Universidad de Buenos Aires. Se trata de fuentes primarias que, estudiadas críticamente en su conjunto y contextualizadas, respaldan la investigación para historizar a Teatro Abierto en sus tres ciclos 1981, 1982 y 1983 -durante la dictadura (1976/1983)-y el diseño de proyectos bajo su nombre o auspicio: (1) La Libertad, luego llamado Teatro Abierto opina sobre la Libertad -finalmente no concretado-; (2) Nuevos Autores, Nuevos Directores; (3) Otro Teatro y (4) Teatrazo 85, realizados en postdictadura
\end{abstract}

La selección aquí propuesta, ordenada cronológicamente, da cuenta en imágenes de un posible trazado para estudiar Teatro Abierto en su primer ciclo, en 1981. Este acontecimiento teatral se sitúa en la Ciudad de Buenos Aires e historiográficamente se corresponde con el pasado reciente, que ocurre durante una fase de la cruenta dictadura cívico-militar argentina (1976/1983). Teatro Abierto no está ajeno al contexto social e histórico en el que surge y puede ser abordado desde diversas disciplinas, con distintas herramientas teóricas.

El 24 de marzo de 1976 asume el gobierno de facto, bajo el argumento de desgobierno, corrupción y subversión -momento en que la guerrilla está derrotada militarmente-, suprime los derechos civiles, las libertades públicas, anula las garantías constitucionales, crea nuevos instrumentos jurídicos, que no sólo buscan "legitimar su dictadura", sino que ya cuenta con instrumentos para operar. Entre ellos, la suspensión de la última parte del artículo 23 de la Constitución Nacional referido al Estado de Sitio, para poner a disposición a numerosas personas detenidas sin derecho a una justa defensa. Se suspenden las actividades políticas, se disuelve la CGT y la CGE, se intervienen sindicatos y federaciones obreras, se suspenden los derechos y las garantías constitucionales para los trabajadores, entre ellos el derecho de huelga, con persecución y muerte de dirigentes. Al mismo tiempo, se establece un férreo control sobre los medios de comunicación, así como la vigilancia de todas las manifestaciones artísticas; la acción coactiva del Estado terrorista busca silenciar todo tipo de opinión. Al inicio 
del golpe, las fuerzas armadas actúan compactas y son acompañadas y sostenidas por sectores de la sociedad civil, empresarial, sindical y parte de la jerarquía eclesiástica. Esto ocurre en consonancia con la etapa del capitalismo financiero internacional y con el objetivo de introducir cambios estructurales y profundos en la sociedad argentina para imponer un plan económico basado en la desindustrialización del país, que en el último tercio del siglo XX tiene un nivel de desarrollo suficiente para abastecer su mercado interno y con una clase trabajadora asalariada que cuenta con un alto grado de organización, conciencia de clase y protagonismo.

Pero para 1980, la dictadura ya no puede ocultar la crisis social, económica, ni la cuestión de los "desaparecidos" que produjo. Por otra parte, al quinto año como lo establecen sus propios estatutos, el gobierno de facto se dispone a cambiar el elenco gobernante, lo que produce disputas de poder para la sucesión prevista. Emilio E. Massera, con aspiraciones políticas personales, previamente en septiembre de 1978 renuncia antes a la junta para presentarse como el "cuarto hombre". Finalmente, Roberto E. Viola reemplaza a Jorge R. Videla como presidente de la junta gobernante representando la continuidad de este último, el sector "aperturista" de las fuerzas armadas, para gobernar como Presidente de la Nación entre marzo y diciembre de 1981. En 1981, es nombrado Lorenzo Sigaut como Ministro de Economía, quien al asumir asegura que "el que apuesta al dólar, pierde"; sin embargo, devalúa en un treinta por ciento el peso respecto del dólar, deja sin efecto la "tablita" impuesta en 1979 por Martínez de Hoz y desdobla el mercado cambiario en dólar financiero y dólar comercial regulado. De todos modos, la crisis económica se torna inmanejable por la liquidación e intervenciones de instituciones bancarias, se incrementa la desocupación, la pobreza, la inflación, el alto endeudamiento externo; y aún, se da comienzo a la estatización de la deuda externa.

En la misma coyuntura 1980-1981, la dirigencia de los partidos políticos -proscriptos y con estado de sitio vigente-, se agrupa en la Multipartidaria que cuenta con apoyo del Episcopado Nacional, emitiendo una serie de documentos públicos críticos, promoviendo "la salida" del régimen y presentando planes de gobierno con el fin de restablecer la democracia institucional.

En la segunda mitad de 1980, un grupo reducido de dramaturgos -Carlos Gorostiza, Carlos Somigliana, Roberto Cossa y el escenógrafo Leandro Ragucci- se reúne para conversar sobre su trabajo y sus problemáticas: no eran convocados por teatros oficiales para representar sus obras. Al grupo inicial, se suma Osvaldo Dragún quien propone organizar un ciclo de teatro argentino en la ciudad de Buenos Aires y así demostrar su existencia. El proyecto es aceptado, extendiéndose la convocatoria para reunir a veintiún autores y veintiún directores que comprometieran a actrices, actores y técnicos a sumarse al proyecto. Alrededor de ciento cincuenta personas terminan organizando el ciclo al que llaman Teatro Abierto. En 1981, los organizadores del ciclo teatral dejan de reunirse en sus casas para hacerlo en la sede de Argentores, donde los autores y autoras leen sus obras colectivamente. Luego, en el Teatro del Picadero comienzan los ensayos. Allí se va a estrenar la programación que cuenta con veinte obras, incluyendo el Espacio Abierto, en horario vespertino, a precios accesibles, a razón de tres obras por día, durante los meses de julio, agosto y septiembre de 1981. El Espacio Abierto se destina a improvisaciones, monólogos, entrevistas y lecturas. Se lo crea en reemplazo de la obra de Oscar Viale, cuyo elenco abandona el proyecto por temor: probablemente para evitar quedar registrados en las "listas negras" existentes en la época, en particular para quienes trabajaban en los canales de televisión dado que todos los estatales estaban dirigidos por interventores representantes del gobierno dictatorial. 
El 28 de julio de 1981, con la lectura de la Declaración los Principios de Teatro Abierto realizada por el actor Jorge Rivera López, se da por inaugurado oficialmente el ciclo Teatro Abierto en el Teatro del Picadero. La sala está colmada de público; las localidades y abonos están agotados.

En la madrugada del 6 de agosto, el Teatro del Picadero sufre un incendio intencional. Con el tiempo, se sabe consumado por disputas políticas, entre las propias fuerzas armadas, aunque los teatristas lo viven como un ataque directo hacia su proyecto y reaccionan para dar una respuesta pública, rápida y contundente. Producen un viraje respecto de la propuesta inicial de los autores cuando los organizadores y participantes del ciclo teatral convocan a una Asamblea en el Teatro Lasalle, acompañados por figuras del ámbito de la cultura, del arte, de la política, por empresarios del teatro comercial, por el público y por la prensa. Allí, se vota por la continuidad del ciclo en el Teatro Tabarís; en ese momento Teatro Abierto se convierte en movimiento teatral de resistencia cultural.

El atentado genera distintos modos de respuestas y acciones de solidaridad por parte de un sector de la sociedad en Buenos Aires; incluso repercute en el exterior, lo que genera una mayor atención sobre el acontecimiento. El caudal de público se multiplica en la sala del Teatro Tabarís que, a pesar de su mayor capacidad respecto del Teatro del Picadero, desborda, como se puede observar en las imágenes fotográficas y cinematográficas que registran las largas filas del público en la calle.

El ciclo de Teatro Abierto finaliza exitosamente el 21 de septiembre de 1981; pero antes de que esto suceda, los organizadores ya preparan el segundo ciclo para 1982.

Los teatristas trabajan con la metáfora y denuncian de manera oblicua en el escenario, las relaciones de dominación crueles y perversas que oprimen a la sociedad del momento; la clase media que conforma el público que los apoya los ovaciona.

Como decíamos, el público estaba conformado en su mayoría, por un sector de la clase media ilustrada; pero ya no es sólo aquel que había sido en años anteriores seguidor del Teatro Independiente -del que a su vez proviene la mayor parte de integrantes de Teatro Abierto-; se suman sectores afines politizados que aplauden los espectáculos al encontrar un espacio de expresión después de años oscuridad, donde aún no se vislumbra la "salida" del régimen dictatorial.

Pronto el sector "aperturista" gobernante va a ser derrotado por el sector de los "duros" que encabeza Fortunato Galtieri, quien mediante el auto-golpe en el interior de las fuerzas armadas, desplaza a Viola. Así se detiene el proceso iniciado en la gestión anterior para volver al plan económico ortodoxo implementado anteriormente por José Martínez de Hoz. Se nombra a Roberto Alemann como Ministro de Economía. No obstante, la crisis se agrava; la población expresa su descontento manifestándose el 30 de marzo de 1982 en la Plaza de Mayo bajo la consigna Pan, Pazy Trabajo, convocada por la CGT Brasil y acompañada por la dirigencia de las pequeñas empresas y los partidos políticos. Y el 2 de abril de 1982, las fuerzas armadas desembarcan inesperadamente en las Islas Malvinas; llevaban soldados que cumplían con el servicio militar obligatorio, sin preparación militar previa, sin ropas ni alimentos adecuados. Se desencadena la Guerra de Malvinas y Argentina se enfrenta con Gran Bretaña, alineada a los EE.UU., lo que lleva a la derrota militar que termina finalmente con la dictadura.

Al contexto de producción de Teatro Abierto, es necesario sumar otros acontecimientos de resistencia que habían comenzado antes del ciclo y que luego continuaron funcionando. Desde 1977, las Madres de Plaza de Mayo, Abuelas de Plaza de Mayo y 
otros organismos van surgiendo a partir de la búsqueda de hijos y familiares detenidos o desaparecidos. En 1979, es clave la visita a la Argentina de integrantes de la Comisión Internacional de Derechos Humanos (CIDH), que en 1980 presenta un informe internacional negativo sobre el gobierno de facto. En 1980, el Parlamento Noruego otorga el Premio Nobel a Pérez Esquivel. Es significativo, que en esta fase de la dictadura el Fondo Monetario Internacional (FMI) cese envíos de dinero o préstamos al gobierno dictatorial. Por su parte, los trabajadores y algunos grupos sindicales enfrentan a la dictadura mediante las huelgas de 1979 y 1981 , respectivamente.

En lo que respecta a actividades culturales y teatrales de resistencia, es necesario registrar prácticas de menor visibilidad, ligadas al teatro militante de los años 70, presentes en Alterarte 1979 y en el Encuentro de las Artes en 1980 y 1981, en la que algunos integrantes de Teatro Abierto, tienen participación.

La prensa antes y durante las funciones de Teatro Abierto, da cuenta del acontecimiento mediante anuncios, editoriales, críticas teatrales, con amplia cobertura fotográfica en diarios y revistas de Buenos Aires y en algunas provincias. A continuación, en este espacio de difusión de testimonios del pasado argentino, se expone una parte de las fuentes del citado archivo.

\section{Bibliografía}

"Villagra, I. (2006). Tesis de Licenciatura en Historia, Facultad de Filosofía y Letras, UBA: Teatro Abierto y Teatro X la Identidad, la historia en el teatro y el teatro en la historia. (Inédita)

»Villagra,I. (2011). Teatro Abierto 1981.Teatro y Teatrología INT-FIBA,1er. Premio Concurso Nacional de Ensayos Teatrales Alfredo de la Guardia 2011,co-editado con Eduardo Del Estal y Manuel Macarini.

"Villagra, I. (2013). Teatro Abierto 1981: Dictadura y Resistencia Cultural. Estudio Crítico de Fuentes Primarias y Secundarias, $1^{\circ}$ Ed. Buenos Aires, Ediciones Al Margen.

"Villagra,I. (2015). Estudio Crítico deFuentes. Historización Teatro Abierto Ciclos 1982 y $1983,1^{\circ}$ Ed. Buenos Aires, Edición de la autora.

»Villagra,I. (2016). El devenir de Teatro Abierto. Estudio Crítico de Fuentes. Historización Teatro Abierto 1984, 1985 y 1986, 1ํEd. Buenos Aires, Edición de la autora. 